\title{
Optimization of equitable irrigation water delivery for a large-scale rice irrigation scheme
}

\author{
Md Rowshon Kamal ${ }^{1 *}$, Muhammad Iqbal ${ }^{2}$, Md Abdul Mojid ${ }^{3}$, Mohd Amin Mohd Soom ${ }^{4}$, Lai Sai $\mathrm{Hin}^{5}$ \\ (1. Department of Biological and Agricultural Engineering, Faculty of Engineering, Universiti Putra Malaysia (UPM), UPM Serdang 43400, \\ Selangor DE, Malaysia; 2. Department of Agricultural Engineering and Technology, Faculty of Agricultural Sciences, Ghazi University, \\ Dera Ghazi Khan, Pakistan; 3. Department of Irrigation and Water Management, Faculty of Agricultural Engineering and Technology, \\ Bangladesh Agricultural University, Mymensingh 2202, Bangladesh; \\ 4. Faculty of Sustainable Agriculture, Universiti Malaysia Sabah (UMS), Jalan UMS, Kota Kinabalu 88400, Sabah, Malaysia; \\ 5. Department of Civil Engineering, Faculty of Engineering, University of Malaya, Kuala Lumpur 50603, Malaysia)
}

\begin{abstract}
Equitable water allocation is essential in an irrigation scheme for obtaining potential crop yields from the entire scheme, especially when water supply is inadequate. An optimization model achieved this goal by coupling an optimal water allocation model with available water supply and irrigation water demand for a river-fed rice irrigation system in Malaysia This model consists of a paddy field water balance module and an optimization module. The outputs from the module are daily irrigation demand and surface runoff, if there is any. The optimization module consists of an objective function, which minimizes water shortage across the scheme area while maintaining equity in water allocation. This model performs optimization subject to several system constraints, and the decision variable of the model is daily releases or supply to the tertiary canals. Performance of this model remained unaffected under different water supply conditions, and the optimization model reliably examined the effects of alternate water allocation and management rules with field information. It improves efficiency and equity in water allocation with respect to crop growth stages and water shortages rather than simply cutting irrigation supply on a proportional basis to overcome water shortages.
\end{abstract}

Keywords: irrigation, optimization, simulation, equitable deliveries, rice

DOI: $10.25165 /$ j.ijabe.20181105.3536

Citation: Rowshon M K, Iqbal M, Mojid M A, Amin M S M, Lai S H. Optimization of equitable irrigation water delivery for a large-scale rice irrigation scheme. Int J Agric \& Biol Eng, 2018; 11(5): 160-166.

\section{Introduction}

Rice is the main staple crop of $\mathrm{Asia}^{[1]}$, and planting of rice request large amount of water resources. Due to rapid population growth, climate change, the deterioration of water quality and increasing competition from other water users, increasing water stress threatens the water availability for irrigated rice production in many Asian countries. Irrigated agriculture provides more food, but irrigation supplies are becoming scarce due to ever-increasing demands on available fresh water. Climate variability and change are adding further uncertainty to future water security and food production $^{[2]}$. Therefore, efficient water allocation is one of the strategies for achieving good water supply condition and water productivity.

The planning and management of a river-fed irrigation system

\section{Received date: 2017-06-03 Accepted date: 2018-07-19}

Biographies: Muhammad Iqbal, Professor, research interests: irrigation and drainage systems, Email: driqbal_cadgk@yahoo.com; Md Abdul Mojid, Professor, research interests: irrigation and water management, Email: ma_mojid@yahoo.com; Mohd Amin Mohd Soom, Professor, research interests: soil and water engineering, Email: mohd.amin@ums.edu.my; Lai Sai Hin, Associate Professor, research interests: hydrology and water resources, Email: laish@um.edu.my.

*Corresponding author: Md Rowshon Kamal, Senior Lecturer, research interest: modeling and simulation of irrigation and water resources, climate-smart agriculture, modeling SDSS for irrigation and water resources, big data application in agriculture. Department of Biological and Agricultural Engineering, Faculty of Engineering, Universiti Putra Malaysia (UPM), UPM Serdang 43400, Selangor DE, Malaysia. Tel: +60389464339, Fax: +60389466425, Email: rowshon@yahoo.com and rowshon@upm.edu.my. mainly depend on the optimal utilization of available river inflows of fluctuating nature for irrigation supply, judicious decision of water allocation strategies, prediction of proper command areas, determination of crop-water demand and cropping pattern to suit water availability and reliability of the irrigation system itself. Decision making on water allocation of an irrigation system involves consideration on different planting schedules, variability in soils, crop conditions, varying water requirements, unreliability in the intake of water in main canal and uneven water allocation to tertiary canals. Equitable water allocation for rice production in large-scale irrigation systems is complex, especially when the available water for irrigation supply is inadequate during each part of the crop season. Proportional sharing of water by each tertiary canal is then necessary. A systematic scheduling of irrigation water that matches with the water requirements of crops in different canal commands is needed to increase crop-water productivity.

Fostering equitable allocation of available water resources for irrigation supply can play vital role in improving the field of water management. It has the greatest effect on water saving in rice production as well as improving water productivity. Linear programming is one of the best tools for optimal allocation of land and water resources ${ }^{[3,4]}$. The robustness of the optimization results on performance variability is crucial for decision support in estimating the impact of different computing environments. A coupled hydrological irrigation optimization modeling system was developed to optimize irrigation strategies for a rice irrigation system in Vietnam ${ }^{[5]}$. Besides, water is often insufficient to irrigate the entire rice production areas during the summer-autumn 
rice season and thus restricted rice productivity significantly in the scheme. Optimal water management of irrigation networks requires consideration of both optimal water delivery scheduling at the canal level and optimal water allocation among different crops at field level ${ }^{[6]}$. At the field level, optimal cropping pattern and water allocation, which maximize crop production and total income, are investigated. At the canal level, optimal water delivery scheduling among different outlets is determined considering predetermined water requirements. But, most irrigation optimization studies ${ }^{[6-8]}$ have been concentrated either at field or canal level separately. Therefore, an integrated approach with the optimization technique is necessary in allocating equitable and improved irrigation water deliveries in rice production.

While Malaysia has plenty of water resources, many areas in the country experience water scarcity due to spatial variability of rainfall. As a result of increasing demand for water resources in various sectors, competition for existing water supplies has become more critical. Growing threats from climate change is intuitively apprehended to further intensify the competition. Consequently, it has become more important than ever to manage water resources efficiently and sustainably. Water in large irrigation schemes is distributed through a network of main, secondary/branch and tertiary canals. In general, irrigation water to tertiary canals is allocated proportionately according to their command areas without considering variations in irrigation demands due to spatial and temporal variability in weather, soil and crops across the irrigation scheme, although the actual water demands and time of delivery among the outlets considerably varies. These variabilities, therefore, make it necessary to reschedule the water deliveries before each rotation $^{[9]}$. Furthermore, when water resources are limited, it becomes necessary to allocate water optimally among water users across an irrigation scheme by considering different soils, crops and climate in the command area. This study, therefore, aims to develop an optimization model for equitable irrigation water allocation among the tertiary canals for a large-scale river-fed rice irrigation scheme in Malaysia by considering an appropriate objective function and constraints.

\section{Methodological approach}

\subsection{Study area}

The Tanjung Karang Rice Irrigation Scheme (TAKRIS) is one of the eight large schemes located at Northwest Selangor in Peninsular Malaysia with a net command area of $15305 \mathrm{hm}^{2}$. The TAKRIS is cultivated twice in a year: August to January, which called the first or wet season, and February to July, which called the second or dry season. The average annual rainfall in the TAKRIS area is $2030 \mathrm{~mm}$ and evaporation is $1600 \mathrm{~mm}$ (The Department of Irrigation and Drainage, Malaysia; DID). Most of the rainfall is concentrated over October-January months, and only to a limited extent over April-May. Therefore, the amount of rainfall is less in the second season than in the first season and, consequently, very often creates a water shortage in the second crop season (February to July) due to prolonged rainless days. The area is used for irrigated rice farming twice in a year, under two cropping seasons, namely: off season during February-July, considered as dry season and main season during August-January, considered as wet season. The highest rainfall is usually received in the month of October and the lowest rainfall is usually received in June. On average, the air temperature is about $28^{\circ} \mathrm{C}$, with a daily variation of $8^{\circ} \mathrm{C}$, monthly humidity is $77 \%$, solar radiation varies from $15.2 \mathrm{MJ} / \mathrm{m}^{2} / \mathrm{d}$ to $20.4 \mathrm{MJ} / \mathrm{m}^{2} / \mathrm{d}$ and windspeed is
$2.25 \mathrm{~m} / \mathrm{s}$. The average monthly values of meteorological data of the study obtained from MMD (Malaysian Meteorological Department).

The irrigation scheme and its water distribution networks under three Irrigation Service Areas (ISAs) are illustrated in Figure 1. The Bernam River is the source of irrigation water, which is diverted through the Bernam River Headwork (BRH). The irrigation water demand is largely supplied by natural rainfall received as effective rainfall within the rice fields (51\%), and the rest comes directly from Bernam River basin. For the management of irrigation water supply, the area is divided into three Irrigation Service Areas (ISAs) (ISA I, ISA II and ISA III), staggered at one month interval during planting. Water is diverted at the Bernam Headworks at a maximum design discharge of $30.6 \mathrm{~m}^{3} / \mathrm{s}$ and is conveyed through a $16 \mathrm{~km}$ unlined Feeder canal into a small river called Tengi where it is channeled by gravity flow the intake point of the main canal. The irrigation water is then delivered to rice fields through off-take structures consisting of constant head orifice structures to 120 tertiary canals. Each canal serves a command area ranging from $20 \mathrm{hm}^{2}$ to $435 \mathrm{hm}^{2}$.

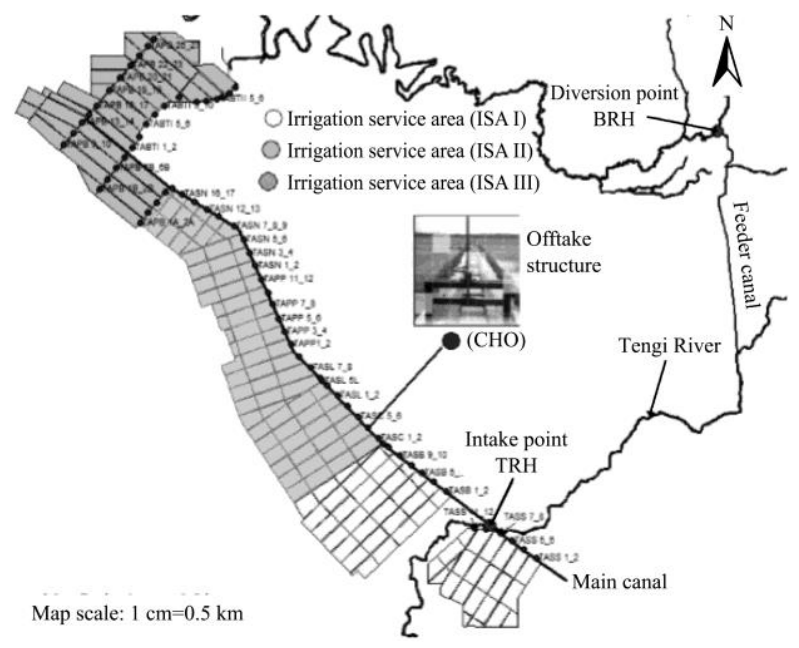

Figure 1 Irrigation service areas (ISAs) and structured irrigation networks of the Tanjung Karang Rice Irrigation Scheme (TAKRIS)

\subsection{Data collection}

Data on daily values of ponding water depth, reference evapotranspiration, crop coefficient, rainfall, seepage and percolation, irrigation efficiency and command area were collected from the relevant government agencies such as IADA Tanjung Karang Rice Irrigation Scheme, The Department of Irrigation and Drainage (DID), Department of Agriculture (DOA), Department of Survey and Mapping Malaysia (JUPEM) and Malaysia Meteorological Department (MMD). Actual daily flows of the tertiary canals were collected from Integrated Agricultural Development Authority (IADA) at Kuala Selangor. The collected data were compiled and verified for their consistency before using in the optimization model.

\subsection{Frameworks of optimization model}

\subsubsection{Water supply in the main canal}

The feeder canal (Figure 1) receives water from the BRH and discharges it at the upstream of the Tengi River Headwork (TRH). The TAKRIS gets its water supply from the TRH through the main canal, which distributes water across the scheme through a network of the tertiary canals. Therefore, available water supply in the main canal must be known a priori in order to efficiently and rationally distribute water among the tertiary canals. Due to conveyance losses of water in the feeder canal and Tengi River, the 
flow rates obtained at $\mathrm{TRH}\left(Q_{\mathrm{TRH}}\right)$ are lower than those at $\mathrm{BRH}$ $\left(Q_{\mathrm{BRH}}\right)$. By using daily discharge data at the BRH $\left(Q_{\mathrm{BRH}}\right)$ and TRH $\left(Q_{\mathrm{TRH}}\right)$, an empirical relation was developed to estimate daily discharge variation at the inlet of the main canal as

$$
Q_{v}=13.2963-\frac{149.5344}{Q_{\mathrm{BRH}}}
$$

where, $Q_{v}$ is the discharge variation, $\mathrm{m}^{3} / \mathrm{s}$, which is the difference between $Q_{\mathrm{BRH}}$ and $Q_{\mathrm{TRH}}$ lagged by one day and obtained at the TRH. The predicted discharge variations (Equation 1) agreed well with the observed discharge variations $\left(r^{2}=0.97\right)$. In this study, Equation (2) was employed to estimate daily discharge at the inlet of the main canal by knowing discharge of the previous day at the inlet of the feeder canal (at BRH) as

$$
Q_{\mathrm{TRH}}(j)=Q_{\mathrm{BRH}}(j-1)-Q_{v}
$$

where, $Q_{\mathrm{TRH}}(j)$ is the discharge at inlet of the main canal, $\mathrm{m}^{3} / \mathrm{s}$ on a particular day $j$ and $Q_{\mathrm{BRH}}(j-1)$ is the discharge at inlet of the feeder canal, $\mathrm{m}^{3} / \mathrm{s}$ on the previous day $(j-1)$.

\subsubsection{Development of optimization model}

An optimization problem consists of an objective function/ performance measure, a set of independent variables, and a set of equality and inequality constraints that constitute the model of the system under consideration ${ }^{[10]}$. Proper formulation of an optimization problem is important since the result of optimization indicates whether the obtained solution is realistic and reliable.

Objective function: water allocation problem addresses one of the issues of ensuring equitable distribution of available water supply within an irrigation scheme. As water shortage persists in TAKRIS, the water allocation problem addresses minimizing this shortage while ensuring equity in the distribution of irrigation water supplies within the scheme. For a given day, the objective function for minimizing water shortage across an irrigation scheme can be expressed ${ }^{[11]}$ as:

$$
\text { minimize } z=\sum_{i=1}^{n} \frac{\left(Q_{\mathrm{dem} i}-Q_{\mathrm{ri}}\right)^{2}}{Q_{\mathrm{dem} i}}
$$

where, $Q_{\mathrm{dem} i}$ is the target water demand/supply for tertiary canal $i$, $\mathrm{m}^{3} / \mathrm{s} ; Q_{\mathrm{r} i}$ is the allocated water supply to tertiary canal $i, \mathrm{~m}^{3} / \mathrm{s}$ and $i$ is the index for tertiary canals $(i=1,2,3 \ldots \ldots n)$.

Constraints: the decision variables in an optimization model often need to satisfy certain constraints in order to be restricted to practically feasible values. The major constraints relevant to water allocation in an irrigation scheme are: water availability constraint, water supply constraint, canal capacity constraint, ponding depth constraint and non-negativity constraint.

Water availability constraint: total allocated water supply to all tertiary canals on any day cannot be more than the available water supply in the main canal on that day. Therefore, a given supply in the main canal has to be allocated among the tertiary canals that:

$$
\sum_{i=1}^{n} Q_{\mathrm{ri}} \leq Q_{j}
$$

where, $Q_{\mathrm{r} i}$ is the allocated water supply to the tertiary canal $i$ and $Q_{j}$ is the available discharge in the main canal on day $j$.

Water Supply Constraint: Depending upon availability in the main canal, water is supplied to each tertiary canal according to its demand that:

$$
Q_{\mathrm{ri}} \leq Q_{\mathrm{dem} i}
$$

where, $Q_{\mathrm{ri}}$ and $Q_{\mathrm{dem} i}$ have the same meaning as in Equation (3).

Canal Capacity Constraint: Canals cannot carry discharge more than their design capacities. Therefore, allocated water supply must not be more than the design capacity of a tertiary canal. This restriction can be expressed as:

$$
Q_{\mathrm{ri}} \leq Q_{\mathrm{des} i}
$$

where, $Q_{\text {desi }}$ is the design capacity $\left(\mathrm{m}^{3} / \mathrm{s}\right)$ of tertiary canal $i$.

Ponding depth constraint: In conventional irrigation system, water is continuously ponded in paddy fields. In TAKRIS, ponding water depth is usually allowed to vary between a minimum of $2.0 \mathrm{~cm}$ and a maximum of $10.0 \mathrm{~cm}$, primarily depending upon the availability of water. When rainfall and/or excess irrigation raises water level beyond a specified maximum ponding $\mathrm{depth} /$ bund height, the excess water is allowed to leave the field as surface runoff. On the other hand, sometimes water supply may not be enough to maintain the minimum ponding depth. In that case, an optimization model will be unable to solve the problem of irrigation water allocation. Therefore, to take care of the possibility of inadequate water supply, saturation of soil (zero ponding depth) was considered as the lower limit of ponding depth in this study. Thus, an additional constraint on ponding depth incorporated in the model is given by:

$$
0 \leq P D_{\mathrm{j}} \leq P D_{\max }
$$

where, $P D_{\mathrm{j}}$ is the ponding depth on day $j$ and $P D_{\max }$ is the maximum ponding depth.

Non-negativity constraint: the non-negativity constraint implies that the value of $Q_{\mathrm{r} i}$ and $Q_{\mathrm{dem} i}$, in no situation, can be less than zero. This constraint is given by:

$$
Q_{\mathrm{ri}}, Q_{\mathrm{dem} i} \geq 0
$$

Irrigation demand for the tertiary canals can be estimated from crop-water requirement, command area and irrigation system efficiency as:

$$
Q_{\mathrm{dem} i}=\frac{I R_{\mathrm{i}} \times A_{\mathrm{i}}}{86.4 E_{\mathrm{s} i}}
$$

where, $I R_{\mathrm{i}}$ is the crop-water requirement in the command area under tertiary canal $i, \mathrm{~mm} / \mathrm{d} ; A_{\mathrm{i}}$ is the command area under tertiary canal $i, \mathrm{hm}^{2} ; E_{\mathrm{s} i}$ is the overall irrigation efficiency, $\%$ and 86.4 is a conversion factor for unit. According to DID and IADA, the average conveyance efficiency was $85 \%$, being $80 \%$ at the tail reaches and $90 \%$ at the head reaches. Taking into account the present conditions of water distribution and operation system, the water distribution efficiency was estimated as $60 \%$. In this study, irrigation application in the TAKRIS is not adjusted in relation to rainfall. The application efficiency was estimated as $95 \%$. The overall project irrigation efficiency was therefore $48.5 \%$.

After making substitutions for $Q_{\mathrm{dem} i}$ (Equation (3)), the complete optimization problem for irrigation water allocation, together with the objective function and constraints, can be rewritten as:

$$
\operatorname{minimize} z=\sum_{i=1}^{n} \frac{\left(86.4 \times I R_{\mathrm{i}} \times A_{\mathrm{i}}-Q_{\mathrm{r} i} \times E_{\mathrm{s} i}\right)^{2}}{86.4 \times I R_{\mathrm{i}} \times A_{\mathrm{i}} \times E_{\mathrm{s} i}}
$$

subject to:

$$
\begin{gathered}
Q_{\mathrm{r} i} \leq Q_{\text {des } i} \\
\sum_{i=1}^{n} Q_{\mathrm{r} i} \leq Q_{j} \\
Q_{\mathrm{ri} i} \leq \frac{I R_{\mathrm{i}} \times A_{\mathrm{i}}}{86.4 E_{\mathrm{s} i}} \\
0 \leq P D_{\mathrm{j}} \leq P D_{\max } \\
Q_{\mathrm{r} i}, I R_{\mathrm{i}} \geq 0
\end{gathered}
$$

Irrigation requirement, $I R$, in a command area is estimated from soil-water balance of the crop fields. Since paddy rice is predominant in the study area, its irrigation requirement was determined from paddy field water balance. For other crops, 
soil-water balance was added to estimate their irrigation requirements. If ponding water on any day becomes less than the required ponding depth, daily irrigation requirement is estimated as the difference between the required and existing ponding water

$$
I R_{j}=\left\{\begin{array}{l}
P D_{d j}-\left(P D_{j-1}+R F_{j}-K_{c j} \times E T_{o j}-S P_{j}\right) \\
0
\end{array}\right.
$$

$\forall\left(P D_{j-1}+R F_{j}-K_{c j} \times E T_{o j}-S P_{j}\right)<P D_{d i}$
$\forall\left(P D_{j-1}+R F_{j}-K_{c j} \times E T_{o j}-S P_{j}\right) \geq P D_{d i}$

where, $P D_{\mathrm{d} j}$ is the desired/allowed ponding water depth on $j$-th day (varies between $2 \mathrm{~cm}$ and $10 \mathrm{~cm}$ ); $P D_{j-1}$ is the ponding water depth on the previous day; $R F_{j}$ is the amount of rainfall occurred on the paddy field, $K_{\mathrm{c} j}$ is the crop coefficient for paddy rice; $E T_{\mathrm{oj}}$ is the reference crop evapotranspiration and $S P_{j}$ is the seepage and percolation loss of water.

Runoff from the field occurs when ponding water depth on any

$$
R O_{j}=\left\{\begin{array}{l}
0 \\
\left(P D_{j-1}+R F_{j}-K_{c j} \times E T_{o j}-S P_{j}\right)-\mathrm{PD}_{\text {max }}
\end{array}\right.
$$

$$
\begin{array}{ll}
\forall & \left(P D_{j-1}+R F_{j}-K_{c j} \times E T_{o j}-S P_{j}\right) \leq P D_{\max } \\
\forall & \left(P D_{j-1}+R F_{j}-K_{c j} \times E T_{o j}-S P_{j}\right)>P D_{\text {max }}
\end{array}
$$

where, $R O_{j}$ is the runoff from the paddy field and $P D_{\max }$ is the maximum specified ponding depth. The meanings of other parameters are as described before. All parameters in Equation (17) are expressed in depth, mm. The ponding water depth is updated at the end of day $j$ with water balance equation as:

$$
P D_{j}=P D_{j-1}+I R_{j}+R F_{j}-K_{c j} \times E T_{o j}-S P_{j}-R O_{j}
$$

where, $I R_{j}$ is the irrigation requirement of crops.

FAO Penman-Monteith method was employed to compute daily reference evapotranspiration, $E T_{\mathrm{o}}$, of a hypothetical reference crop according to Allen et al. ${ }^{[12]}$ Crop coefficients $\left(K_{c}\right)$ for paddy were obtained from $\mathrm{JICA}^{[13]}$. A regression equation was fitted to estimate daily $K_{\mathrm{c}}$ value as:

$$
K_{c j}=\frac{1.14996-0.23531 \times j^{0.5}+0.01387 \times j}{1.0-0.194 \times j^{0.5}+0.00087 \times j+0.00021 \times j^{1.5}}
$$

where, $K_{\mathrm{c} j}$ is the crop coefficient on $j$-th day and $j$ is the number of days since planting. Equation (19) closely estimates the observed crop coefficient with large coefficient of determination $\left(r^{2} \approx 1.0\right)$.

Current data on seepage and percolation rates in the paddy fields of the study area was not available. Based on the field day becomes greater than the specified maximum depth $(10 \mathrm{~cm})$. Runoff is calculated as the difference of current ponding depth and specified maximum depth. The final ponding depth at the end of each day is updated and limited to the maximum specified depth. The runoff flows towards nearby drains and/or low-lying area was estimated by:

investigation, the seepage and percolation rates of $2.0 \mathrm{~mm} / \mathrm{d}$ that accounted $^{[13,14]}$ through a study conducted in five irrigation compartments of TAKRIS were used in this study. Seepagepercolation (SP) were measured using three field lysimeters in paddy five lots in the scheme that values ranged from $0.80 \mathrm{~mm} / \mathrm{d}$ to $2.22 \mathrm{~mm} / \mathrm{d}^{[14]}$. Detail information on spatial variation in soil and water table condition was also not available for the study area. As soil variability and water table condition have direct effects on irrigation water requirements of paddy rice through seepage and percolation rates, the concept of spatial variability was incorporated by assigning appropriate seepage and percolation rates for the command area of the individual tertiary canals.

\subsubsection{Optimization of water allocation}

The appropriate solution of an optimization model depends on the mathematical form of the objective function and equations of the constraints therein. Firstly, the optimization problem (objective and constraints) was converted/written into algebraic and logical formulas in appropriate cells in Excel worksheet. Then Excel Solver Dialog Box was invoked through Data Analysis Tool Menu shown in Figure 2.

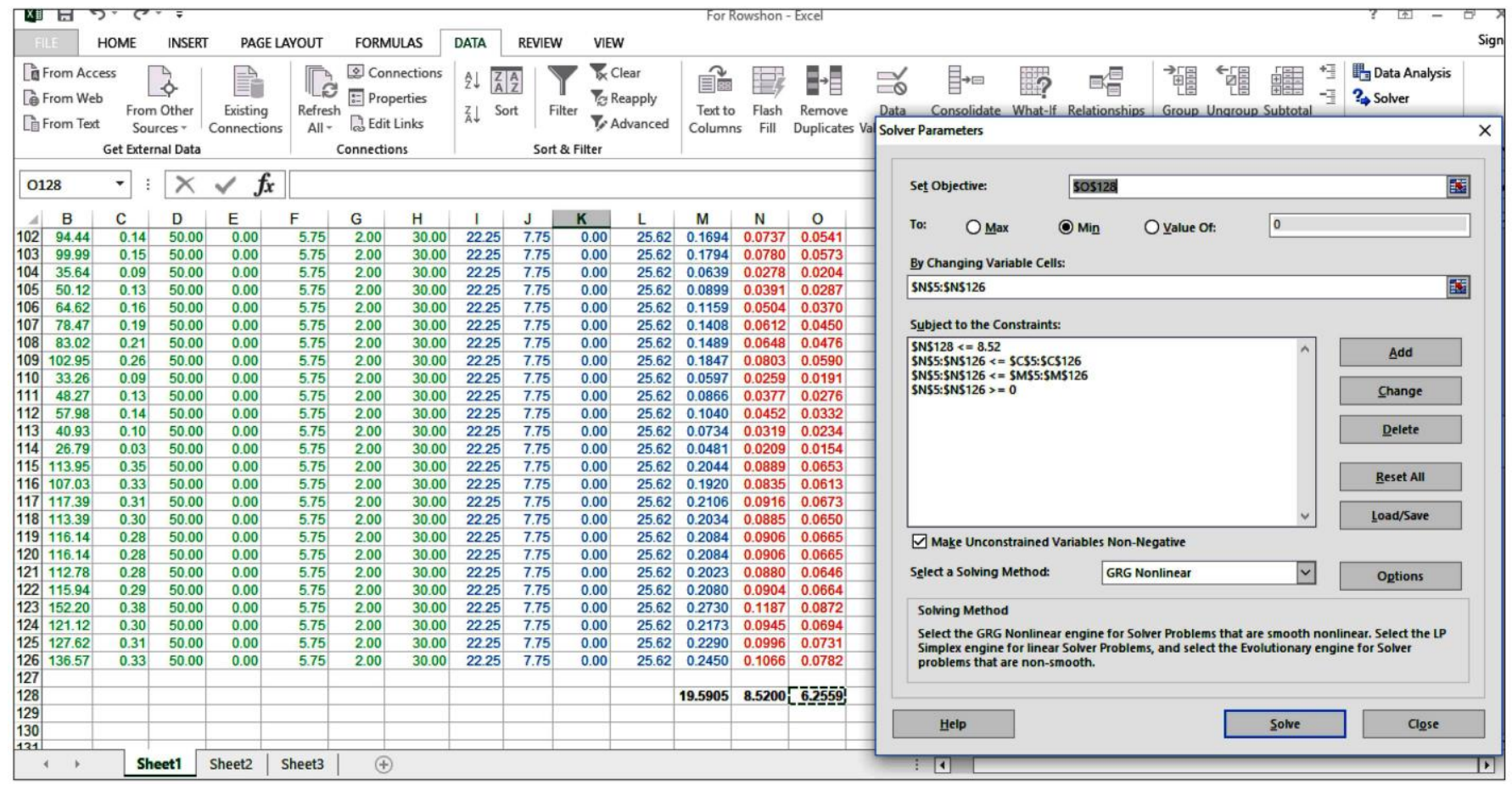

Figure 2 Dialog box showing the optimization computation using MS Excel Solver 
Objective function, decision variables and constraints were specified in the Solver Dialog Box by specifying the relevant cells in the Excel worksheet. After setting options for precision, number of iterations and solving method, Solve Tab on the Solver Dialog Box optimized the problem and returned the values of objective function, decision variables and constraints in the Excel Sheet, as shown in the part of the screenshot given in the following Figure 2. Completed optimization process can be repeated over each day of the growing seasons by writing VBA Code for looping. A step-by-step schematic flowchart (Figure 3) illustrates the procedure of optimizing water allocation for the tertiary canals as the season advances.

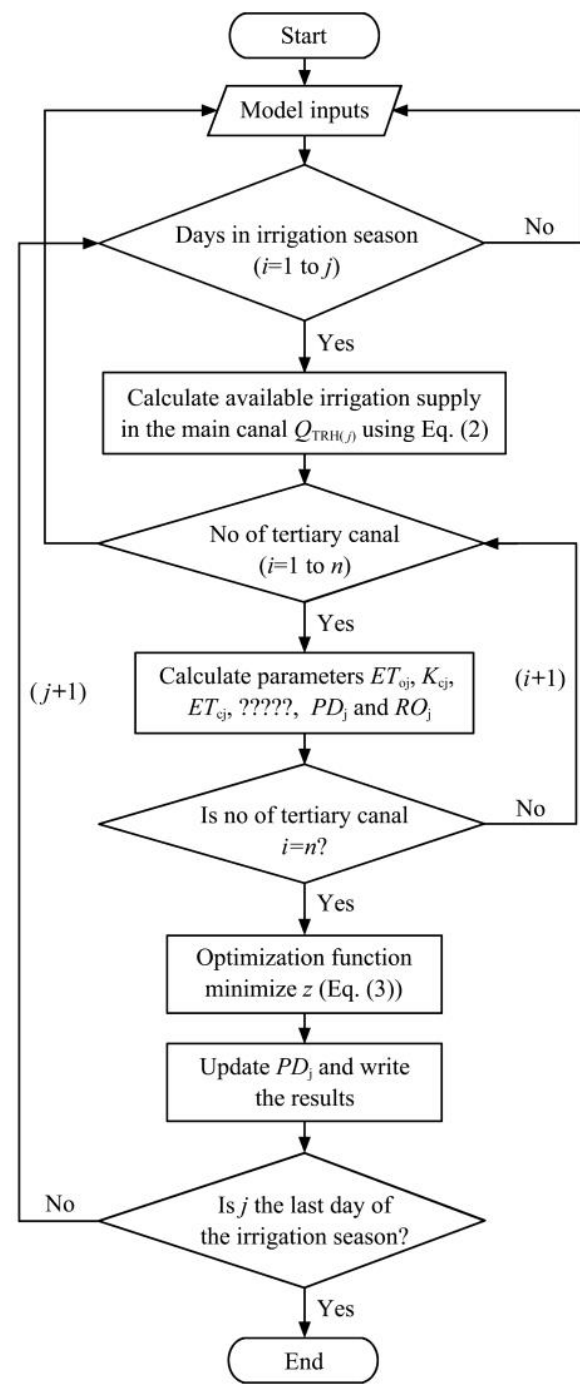

Figure 3 Schematic flowchart of optimizing water allocation

\subsection{Application of optimization model to a case study}

The optimization model was applied to TAKRIS to allocate available water supply at TRH equitably to the tertiary canals (for crop area of the scheme). Required inputs for application of the model are: daily values of rainfall $\left(R F_{j}\right)$, reference evapotranspiration $\left(E T_{\mathrm{o}}\right)$, crop coefficient $\left(K_{c}\right)$, current ponding water depth $\left(P D_{j-1}\right)$, seepage and percolation rate $\left(S P_{j}\right)$, desired ponding depth $\left(P D_{j}\right)$ and maximum ponding depth $\left(P D_{\max }\right)$ for the command area of each tertiary canal under consideration. The output of the model consists of updated ponding depth $\left(P D_{j}\right)$, required water supply $\left(Q_{\mathrm{dem} i}\right)$ based on irrigation requirements $\left(I R_{j}\right)$, runoff $\left(R O_{j}\right)$, recommended water supply $\left(Q_{\mathrm{r} i}\right)$ and relative water supply $\left(Q_{\mathrm{ri}} / Q_{\mathrm{dem} i}\right)$. The required water supply is calculated by Equation (9). Field data of tertiary canals of the TAKRIS (Table
1) was used to test the model. The functioning of the model was tested for the assumed lower $\left(8.52 \mathrm{~m}^{3} / \mathrm{s}\right)$ and higher $\left(22.21 \mathrm{~m}^{3} / \mathrm{s}\right)$ inflows than the actual average inflow $\left(18.21 \mathrm{~m}^{3} / \mathrm{s}\right)$ at TRH. The model was run to allocate the available water supply to paired tertiary canals equitably.

Table 1 Field data of tertiary canals of the Tanjung Karang Irrigation Scheme (TAKRIS) for input of the optimization model

\begin{tabular}{lccc}
\hline \multirow{2}{*}{\multicolumn{1}{c}{ Model parameters }} & \multicolumn{2}{c}{ Irrigation service area } \\
\cline { 2 - 4 } & ISA-I & ISA-II & ISA-III \\
\hline Present ponding water depth, $P D_{j-1} / \mathrm{mm}$ & 43.18 & 41.0 & 30.0 \\
Recommended ponding water depth, $P D_{j} / \mathrm{mm}$ & 39.0 & 35.0 & 30.0 \\
Seepage and percolation, $S P_{j} / \mathrm{mm}$ & 2.0 & 2.0 & 2.0 \\
Days after sowing, $j$ & 81 & 50 & 20 \\
Reference evapotranspiration, $E T_{\mathrm{o}} / \mathrm{mm}$ & 5.19 & 5.06 & 5.0 \\
Paddy crop coefficient, $K_{c j}$ & 1.4 & 1.35 & 1.15 \\
Expected rainfall, $R F_{j} / \mathrm{mm}$ & 0 & 0 & 0 \\
Bund $/$ dike height, $P D_{\mathrm{max}} / \mathrm{mm}$ & 100 & 100 & 30 \\
Irrigation efficiency, $E_{\mathrm{s} i} / \%$ & 58.0 & 55.0 & 50.0 \\
Inflow at TRH $/ \mathrm{m}^{3} \cdot \mathrm{s}^{-1}$ & & 18.21 & \\
\hline
\end{tabular}

\section{Results and discussion}

Figure 4 depicts the design discharge, water demand/target supply, recommended/allocated supply and relative supply for paired tertiary canals. The optimization model provided equitable distribution of available water supply in the main canal to the tertiary canals. However, there is a discrepancy in the pattern of water allocation for the tertiary canals TAPB 16_17 and TAPB 28. The model allocated lower supplies to these canals compared to rest of the tertiary canals. The relative water supply was 0.853 for TAPB 16_17 and 0.703 for TAPB 28 against the relative water supply of 0.931 for rest of the tertiary canals in the scheme. The reason for lower allocated supplies to these tertiary canals was their lower design capacities compared to their required capacities based on demand. The water demand for TAPB $16 \_17$ was $0.3489 \mathrm{~m}^{3} / \mathrm{s}$ and that of TAPB 28 was $0.0481 \mathrm{~m}^{3} / \mathrm{s}$ against their design capacity of $0.2976 \mathrm{~m}^{3} / \mathrm{s}$ and $0.034 \mathrm{~m}^{3} / \mathrm{s}$, respectively. The capacity constraint (Equation (6)) thus forced the optimization model not to allocate larger supply than the capacity of the tertiary canals, although the supply was available and larger demand was existed. It is therefore revealed that the capacity of the tertiary canals TAPB 16,17 and 28 needs to be increased for accommodating larger supplies to satisfy requirements of their command areas. Otherwise, the command areas under these tertiary canals need to be reduced to remove the observed discrepancy.

Figure 5 illustrates the recommended irrigation supplies provided by the optimization model (Equation (18)) for the paired tertiary canals on 20 October 2014. Model provided very close results in allocating water supplies up to the tertiary canal TASL 5R_6 (Figure 4). The optimization model allocated the available supply of $18.21 \mathrm{~m}^{3} / \mathrm{s}$ against a total demand of $19.59 \mathrm{~m}^{3} / \mathrm{s}$, more equitable to individual tertiary canals throughout the scheme.

Figures 6 and 7 show equitable water allocations among the tertiary canals based on an assumed higher $\left(22.21 \mathrm{~m}^{3} / \mathrm{s}\right)$ and a lower $\left(8.52 \mathrm{~m}^{3} / \mathrm{s}\right)$ supplies than the available average water supply, respectively. For the higher supplies, the capacity constraint (Equation (7)), as in Figure 4, forced the optimization model not to allocate supply larger than the capacity of the tertiary canals. As the available supply was not enough for the lower supply case, the 
model therefore allocated supplies lower than the design capacities of the tertiary canals TAPB 16, 17 and 28 in Figure 7.

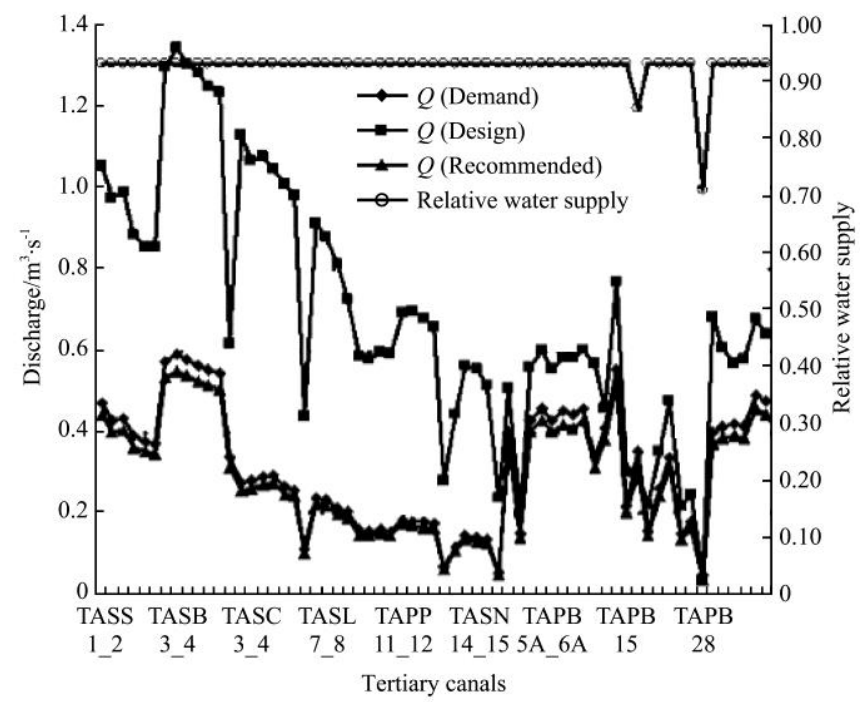

Figure 4 Optimized water allocation among individual tertiary canals with actual available inflow at TRH $\left(18.21 \mathrm{~m}^{3} / \mathrm{s}\right)$ in

October 2014

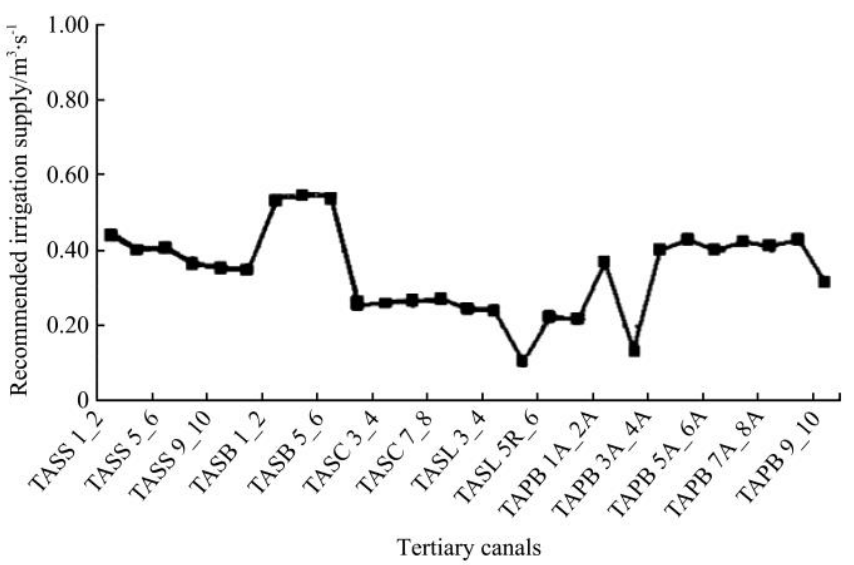

Figure 5 Comparison of recommended irrigation water supply estimated by the optimization model (Equation (18)) with that of the equitable water distribution model (Equation (1))

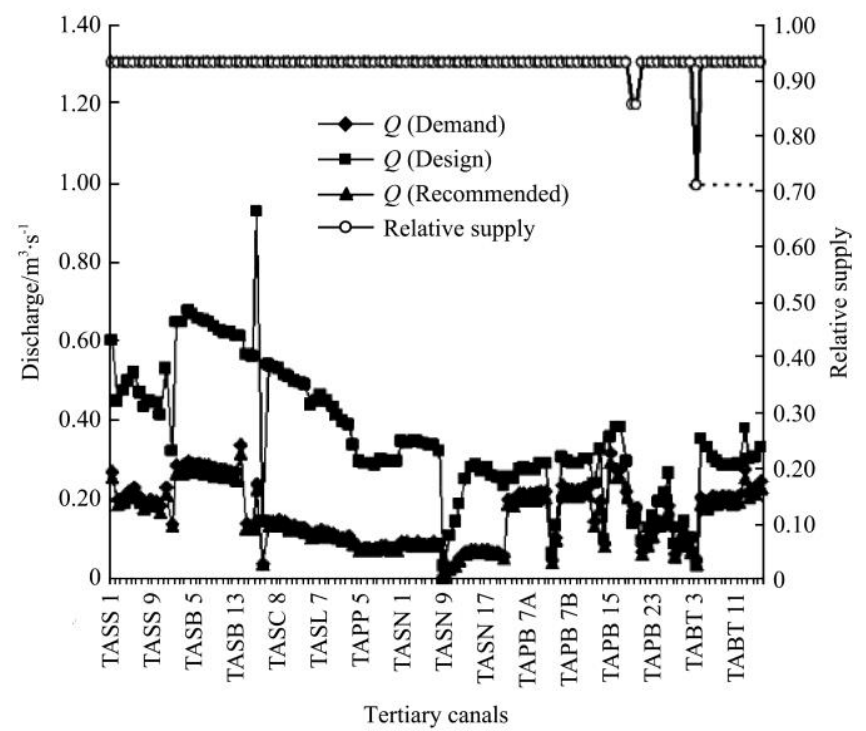

Figure 6 Optimized water allocation among individual tertiary canals with assumed high inflow rate at TRH $\left(22.21 \mathrm{~m}^{3} / \mathrm{s}\right)$ in

October 2014

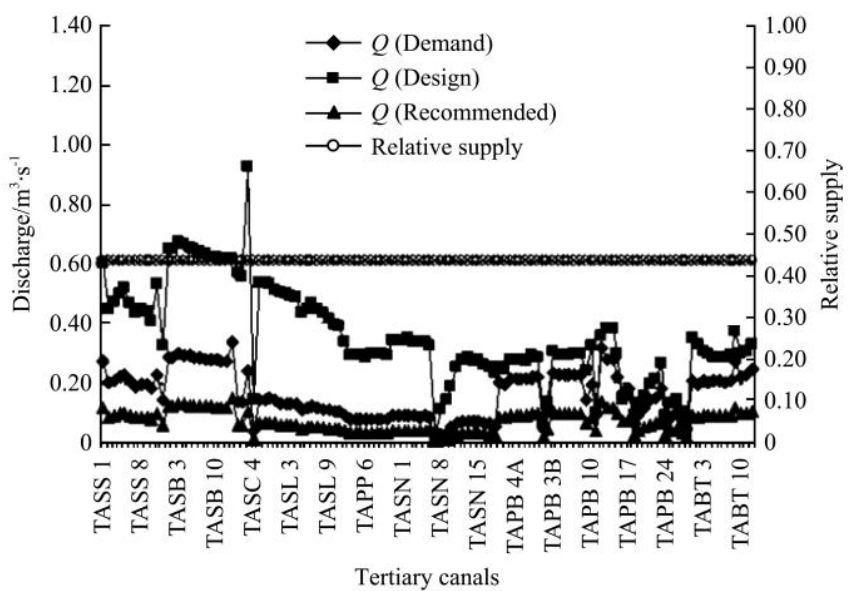

Figure 7 Optimized water allocation among individual tertiary canals with assumed low inflow rate at TRH $\left(8.52 \mathrm{~m}^{3} / \mathrm{s}\right)$ in October 2014

Optimization model under actual available supply, assumed higher and lower available supplies was found capable of making equitable water allocations under any situations. The optimization model is more suitable for making equitable water allocation, especially in the case of water shortage scenario.

\section{Conclusions}

An optimum water allocation model for equitable irrigation supply was developed and evaluated for 120 tertiary canals of a large-scale Tanjung Karang rice irrigation system in Malaysia. The model is capable of accurately determining the available water demand for irrigation and simulating the recommended periodic irrigation supply for the tertiary canals. To optimize equitable irrigation supplies among the tertiary canals, the recommended irrigation supply must be less than or equal to the allowable irrigation supply for each canal, taking the actual cropped area and water demand into account. The optimization model provides a proper operation of irrigation off-take structures by an irrigation manager. The model represents a practical solution to the problem of providing a proportionate allocation and equitable distribution of available water resources for the tertiary canals of the irrigation scheme.

The proposed optimization model is capable of optimizing water allocations across the Tanjung Karang Rice Irrigation Scheme (TAKRIS), performed better than simulation techniques for making equitable allocations of scarce water supplies. The model identified three tertiary canals (TAPB 16, 17 and 28) having smaller design capacities than required for their command area, is capable to determine equitable water allocation accurately for TAKRIS. The current approach in the model is limited to making water allocations to a rice irrigation scheme only, and an additional soil-water balance module for crops other than rice can be incorporated so that the model can be used in multi-crop irrigation schemes. It can be simply adapted to other areas by modification based on local hydro-meteorological data and information of the irrigation scheme. The capability of the model can be extended by embedding it into GIS or vice versa through a user-friendly Graphical User Interface (GUI). Real-time monitoring and prediction of various factors that influence the management of irrigation and water resources are also needed to improve model performance. 


\section{Acknowledgements}

The authors gratefully acknowledge the financial support of the Ministry of Science, Technology and Innovation, Malaysia. They also acknowledge the Department of Irrigation and Drainage, Tanjung Karang Irrigation Scheme, Department of Surveying, Malaysia, and Malaysian Meteorological Department for providing relevant information for this study.

\section{[References]}

[1] Wassmann R, Sumfleth K, Pathak H, Howell G, Ismail A, Serraj E. Regional vulnerability of regional climate change impacts on Asian rice production and scope for adaptation. Advances in Agronomy, 2014; 102: 91-133.

[2] International Water Management Institute, IWMI. Strategy 20140-2018: Solution for water secured world. Annual Report, Colombo, Sri Lanka, 2014.

[3] Panda S N, Khepar S D, Kaushal, M P. Stochastic irrigation planning: An application of chance constrained linear programming. Journal of Agricultural Engineering, 1985; 93-105.

[4] Paul S, Panda S N, Kumar D N. Optimal irrigation allocation: A multilevel approach. Journal of Irrigation and Drainage Engineering, 2000; 126(3): 149-156.

[5] Development of an integrated hydrological-irrigation optimization modeling system for a typical rice irrigation scheme in Central Vietnam. Agricultural Water Management, 2018; 208: 193-203.
[6] Kanooni A, Monem M J. Integrated stepwise approach for optimal water allocation in irrigation canals. Irrigation and Drainage, 2014; 63(1): $12-21$.

[7] Monem M J, Namdarian R. Application of simulated annealing (SA) techniques for optimal water distribution in irrigation canals. Irrigation and Drainage, 2005; 54(4): 365-373.

[8] Georgiou P E, Papamichail D M, Vougioukas S G. Optimal irrigation reservoir operation and simultaneous multi-crop cultivation area selection using simulated annealing, Irrigation and Drainage, 2006; 55(2): 129-144.

[9] Wang J X, Huang Z J, Rozelle S. Incentives in water management reform: assessing the effect on water use, production, and poverty in the Yellow River Basin. Environment and Development Economics, 2005; 10: 769-799.

[10] Reklaitis G V, Ravindran A, Ragsdell K M. Engineering optimization method and application. Wiley, New York, 1983.

[11] Wardlaw R, Barnes J. Optimal allocation of irrigation water supplies in real time. Journal of Irrigation and Drainage Engineering, 1999; 125(6): 345-354.

[12] Allen R G, Pereira L S, Raes D, Smith M. Crop evapotranspirationguidelines for computing crop water requirements-FAO Irrigation and drainage. FAO, Rome, 300, 6541, 1998; 56.

[13] JICA (Japanese International Corporation Agency). The study on modernization of irrigation water management system in the granary areas of Peninsular Malaysia. Nippon Koei Co., Ltd; 1998.

[14] Rowshon M K, Amin M S M, Hassan S M H, Shariff A R M, Lee T S New performance indicators for rice-based irrigation systems. Paddy and Water Environment, 2006; 4(2): 71-79. 